\title{
Review Article \\ Estrogens and Spermiogenesis: New Insights from Type 1 Cannabinoid Receptor Knockout Mice
}

\author{
Giovanna Cacciola, Teresa Chioccarelli, Silvia Fasano, \\ Riccardo Pierantoni, and Gilda Cobellis \\ Dipartimento di Medicina Sperimentale, Sez. Bottazzi, Seconda Università di Napoli, Via Costantinopoli 16, 80138 Napoli, Italy
}

Correspondence should be addressed to Riccardo Pierantoni; riccardo.pierantoni@unina2.it

Received 16 August 2013; Accepted 26 September 2013

Academic Editor: Natalia Battista

Copyright (C) 2013 Giovanna Cacciola et al. This is an open access article distributed under the Creative Commons Attribution License, which permits unrestricted use, distribution, and reproduction in any medium, provided the original work is properly cited.

\begin{abstract}
Spermatogenesis is a complex mechanism which allows the production of male gametes; it consists of mitotic, meiotic, and differentiation phases. Spermiogenesis is the terminal differentiation process during which haploid round spermatids undergo several biochemical and morphological changes, including extensive remodelling of chromatin and nuclear shape. Spermiogenesis is under control of endocrine, paracrine, and autocrine factors, like gonadotropins and testosterone. More recently, emerging pieces of evidence are suggesting that, among these factors, estrogens may have a role. To date, this is a matter of debate and concern because of the agonistic and antagonistic estrogenic effects that environmental chemicals may have on animal and human with damaging outcome on fertility. In this review, we summarize data which fuel this debate, with a particular attention to our recent results, obtained using type 1 cannabinoid receptor knockout male mice as animal model.
\end{abstract}

\section{Introduction}

Spermatogenesis occurs in the testis in a stepwise fashion so that committed spermatogonia proliferate and develop into spermatocytes (SPC) to enter meiosis and produce round spermatids (SPT). These undergo a morphological transformation (spermiogenesis) into mature SPT (i.e., spermatozoa), which are differentially released from Sertoli cells (spermiation) depending on the species. In mammals, further transformations occur in the epididymis to form mature spermatozoa (SPZ) suitable for fertilization [1-4]. Spermatogenesis is a process highly conserved throughout vertebrate species and it is mainly under hypothalamic-pituitary control [517]. Indeed, it is a hormonally controlled mechanism; apart from gonadotropins and androgens, numerous endocrine, paracrine, or autocrine factors converge in a complex stagespecific multifactorial control of spermatogenesis [10, 18-24].

Spermiogenesis is the terminal differentiation process of male germ cells, during which haploid round SPT undergo extensive biochemical and morphological changes including acrosome formation, flagellar development, chromatin condensation, and severe nuclear and cellular reorganization
$[25,26]$. In mouse, morphological criteria have been used to classify spermiogenesis in 16 developmental steps [27]; in particular, round (steps 5-8), elongating (steps 9-11), condensing (steps 12-14), and condensed (steps 14-16) SPT are differentially characterized by acrosomal and flagellar development, as well as by cellular and nuclear shape. During the early steps, round SPT are transcriptionally active; in elongating SPT, transcriptional activity decreases and then turns off; later, in condensing SPT, an extensive chromatin reorganization occurs at molecular and morphological levels [28].

The underlying events that lead to this extensive chromatin reorganization and packaging have been reported in several excellent reviews and here summarized, but very little is known about the molecular mechanisms involved $[26,29-32]$. Interestingly, in recent overviews about estrogens $\left(E_{2}\right)$ and spermatogenesis in mammals, the presence of $E_{2}$ receptor (ER) and aromatase in somatic and germ cells has been underlined to suggest a possible involvement of this traditionally female hormone in spermiogenesis [2, 33-36].

In this review, we focus on the recent advances in our laboratory about the emerging role of $\mathrm{E}_{2}$ in SPT chromatin reorganization during spermiogenesis. In particular, new 
insight has come out from the study of type 1 cannabinoid receptor knockout $\left(\mathrm{Cnrl}^{-/-}\right)$mice.

\section{Chromatin Reorganization in SPT}

Spermatozoa are highly differentiated haploid cells with a particular chromatin organization that results from remodeling events occurring during meiotic and postmeiotic phases of spermatogenesis [26].

Indeed, when cells enter the meiotic prophase, all the somatic histones, except H4 (i.e., H4t-gene protein), are replaced by testis-specific (TH2A, TH2B, TH3, and H1t) or testis-enriched (H2AX, H1a) histone variants [37-39]. Testicular variants of H1 linker are H1t, H1t2, and HILS1 [4042]. Among these, H1t has been reported to exert the lowest condensing effect on rat testis oligonucleosomes [43]. The high levels of H1t (about 55\% of the linker histones) during the pachytene phase until the stage of elongating SPT suggest a role in keeping chromatin in a relatively decondensed state which enables nuclear events. Indeed, during the early steps, round SPT are transcriptionally active and contain H1tenriched nucleosomal chromatin. In elongated SPT, H1t persists until the transcriptional activity of the genome is still detectable [37]. This histone-variant incorporation step, together with histone posttranslational modifications, such as acetylation, methylation, ubiquitination, and phosphorylation, creates specific chromatin domains characterized by quickly disassembling nucleosomes and by a new "histone code," both facilitating histone displacement [39, 44, 45].

During the postmeiotic stage of spermatogesis, when round SPT are extensively remodelled to form mature SPZ, a gradual and radical change in the chromatin cytoarchitecture is observed (the main events are summarized in Figure 1) [46]. This extensive chromatin reorganization requires (i) expression and storage of specific proteins involved in condensation, such as transition proteins (TNP) and protamines (PRM), (ii) transient DNA strand-breaks which require the topoisomerase enzyme, (iii) displacement and degradation of the nucleosomal structure, (iv) sequential histone replacement, firstly by TNP and then by PRM, (v) transcriptional silencing and DNA repair, and (vi) repackaging of protaminated chromatin into toroidal structures $[47,48]$. However, many species retain a small fraction $(1 \%$ in mouse, $15 \%$ in human) of their chromatin in the more relaxed nucleosomal configuration [49] so that SPZ contain at least two differentially packaged chromatin domains: (1) the PRM-based chromatin that organizes the bulk of DNA in a highly compact toroidal configuration, suitable to arrest transcription and mask genome from exogenous and endogenous damage until fertilization [29]; (2) the nucleosome-based chromatin that organizes epigenetically marked developmental loci in a potentially dynamic transcriptional configuration, useful after fertilization $[30,50]$. Interestingly, early after fertilization, before activation of the embryonic genome, the paternal pronucleus becomes highly transcriptionally active compared with the female pronucleus [51].

At molecular level, histone-to-PRM exchange requires the expression and storage of specific mRNA involved in condensation. Indeed, transcription and translation are temporally uncoupled. Tnp1/2 and Pmr1/2 mRNAs are synthesized and stored for some days in SPT and later translated, implying a timely controlled process of haploid-regulated transcription and translation $[28,52,53]$. In particular, Tnp1 and Tnp2 mRNA are preserved in translationally inert ribonucleoprotein particles; afterward, they are translated in elongating-condensing SPT (steps 10-15 of spermiogenesis) and then degraded after translation $[52,53]$. Temporal and stage-specific appearance of TNP and PRM is strictly regulated and is prerequisite for the correct differentiation of round SPT into mature and motile SPZ with fertilizing capability [54].

Transcriptional regulation of haploid genes depends on potentiation of gene via association with nuclear matrix attachment regions (MARs) [55]. It also depends on DNA methylation and recruitment of transacting factors like TATA-box protein (TBP), Y-box proteins, and cAMP-responsive element modulator (CREM). The latter is a transcription factor which binds as homo- and heterodimers to the regulatory sequence CRE (cAMP-responsive element) $[29,56]$. The CREM-encoding gene is highly expressed in the adult testis and shows multiple site of alternative splicing [57]. Levels of CREM transcripts are low in prepubertal testis and only the repressor isoforms $(\alpha, \beta)$ are detected. However, during puberty, transcripts encoding the activator form CREMtau $(\mathrm{CREM} \tau)$ appear abundantly expressed only in germ cells, from the pachytene SPC stage onward, while CREM $\tau$ protein is not detected in SPC but only in haploid SPT at very high levels $[57,58]$. The CREM switch (repressor versus activator) is regulated by the gonadotropin FSH which, acting through Sertoli cells, paracrinally directs the use of an alternative polyadenylation site in SPT, resulting in a more stable CREMt transcript [59]. Many haploid genes have been identified as potential CREM targets since they contain CREs or half CRE in their promoters. Indeed, CREMt regulates gene expression of Tnp and Prm $[29,56]$.

In mouse, Pmrl, Pmr2, and Tnp2 genes are clustered on chromosome 16 and, contrary to the usual paradigm, they are fully methylated when actively transcribed. In contrast, the Tnpl gene shows demethylation in the $5^{\prime}$ region associated with gene activity [38]. In humans, the DNA methyltransferase 1 (DNMT1) is restricted to male germ cells (pachytene SPC and round SPT), and infertile patients showing round SPT maturation arrest also show a specific DNMT1 loss in these cells [60]. Similarly, Crem-null mice show round SPT maturation arrest $[61,62]$. These observations suggest that methylation and CREM are master controllers of SPT differentiation.

In mouse, histone displacement starts at step 9. Main events promoting histone displacement are phosphorylation of histone $\mathrm{H} 1 \mathrm{t}[63]$ and hyperacetylation of $\mathrm{H} 4$. The latter process has been largely studied in germ cells of several species [64-66] and is largely conserved during evolution. It has been demonstrated that hyperacetylation of histone tails (steps 8-11 SPT) relaxes nucleosomal DNA-histone interaction, and precedes and overlaps either histone displacement or TNP1/TNP2 presence at nuclear level (step 10-early 15 SPT). Accordingly, core-histones are displaced in their acetylated 


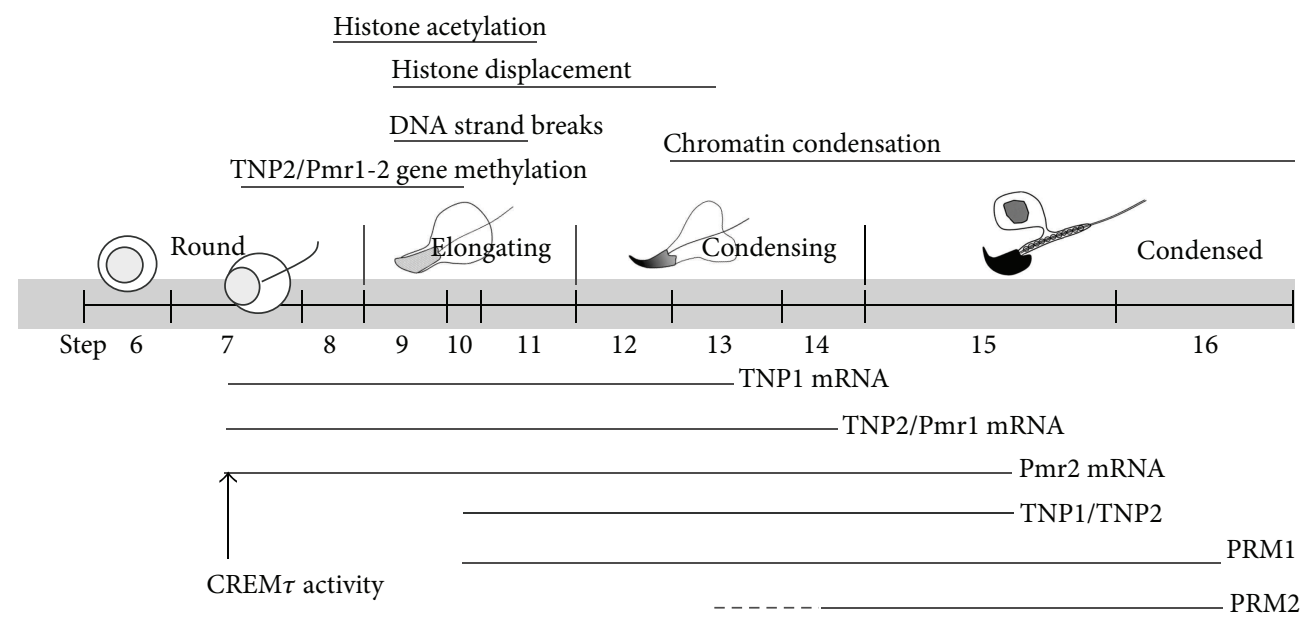

FIGURE 1: Timing of the main chromatin remodeling events in round, elongating, condensing, and condensed spermatids (the related references are reported in the text).

state [66]. Available reports suggest that the process of histone displacement requires (i) DNA nick/repair induced by topoisomerase which relieves torsional stress associated with histone-to-PRM exchange; (ii) hyperacetylation of histone tails by histone acetyl transferase with a concerted down regulation of histone deacetylase; (iii) histone removal mediated by the recruiting protein BRDT (testis-specific bromodomain protein) able to bind histone acetylated lysines, and (iv) acetylated histone degradation through polyubiquitylation of $\mathrm{N}$-terminal lysines [31]. Histone displacement ends at step 13 SPT [47].

Concurrently to the aforementioned steps, a DNAbinding competition mechanism leads to histone-to-TNP exchange (TNP1-4 in mice, rats, boars, bulls, and men; the best characterized are TNP1 and TNP2) and to final TNP-toPRM transition (PRM1 in rats; PRM1 and PRM2 in stallions and mice; PRM 4 in humans) [39, 47]. Phosphorylation and dephosphorylation of TNP and PRM trigger their nuclear translocation, their binding to DNA, and eventually chromatin condensation $[28,67]$. It has been demonstrated that TNP1 has important DNA-nucleosome core destabilizing properties because it decreases the melting temperature of DNA and relaxes DNA in nucleosomal core particles in vitro [68]. In contrast, TNP2 seems to be a DNA-condensing protein [69] and its phosphorylation by protein kinase A greatly reduces its condensation property [70]. Although TNP1 and TNP2 apparently show distinct functions, together with PRM, both are involved in DNA strand-break repair $[53,71-$ 74] and male mice with single tnp1 or tnp2 gene deletion demonstrate that TNP1/2 partially complement each other and both affect PRM2 processing before its binding to DNA [75]. Interestingly, in double Tnp1/Tnp2-null mice, histone displacement and PRM deposition proceeded relatively normally, chromatin condensation occurs irregularly, and many SPT show DNA breaks, thus demonstrating that although TNP are required for a normal chromatin condensation, they are not essential for the process [76].

Protamines are the most basic DNA-condensing proteins. Most likely, they arise from an ancestral histone H1 gene [77], but, differently from histones, they are characterized by arginine (in eutherians, arginine, and cysteine) rather than lysine residues [78]. This biochemical difference explains PRM greater affinity for DNA, due to a higher hydrogen binding potential of arginine over lysine [79]. These proteins may bind to the major and minor groove of DNA or to the DNA surface by interacting electrostatically with phosphate residues. It has been demonstrated that PRM allow chromatin condensation through arginine residues into toroidal structures at testicular level [29], and further through cysteine residues along the epididymal transit, when inter- and intraprotamines disulphide bonds are formed [80]. In concert with thiol oxidations, PRM also undergo tyrosine phosphorylation during caputto-cauda transit [81].

At morphological level, when histone-to-PRM transition occurs, an extraordinary event is observed in the nucleus of differentiating germ cells: flocculent densities of chromatin coalesce into a coarsely granulofibrillar chromatin, which gradually extends in a centripetal and rostral-tocaudal direction and becomes dense and homogeneous at the end of spermiogenesis [28]. This chromatin condensation in toroidal structures modifies the shape of the whole nuclear compartment and strongly reduces its size promoting development of the peculiar elongated, small, and hydrodynamic sperm head that supports swimming ability. Indeed, by stacking these toroids, the sperm nucleus achieves a higher efficiency in packaging the paternal genome and therefore in reducing its size to an absolute minimum [30]. The mechanism by which PRM induce the conformational change in chromatin packaging is not well understood, but it is probably related to PRM properties and to enzymes involved in chromatin remodeling $[29,56]$.

Abnormal sperm histone or PRM content can disrupt chromatin organization [82-84]. Indeed, histone retention decreases nucleoprotamine-based chromatin and exposes a more relaxed chromatin to damage $[56,85]$. In both humans and animals, abnormal DNA damage is associated with compromised fertility and increased miscarriage rates $[56,76$, 86]. Therefore, chromatin quality is an objective marker of 
sperm function that provides a significant prognostic factor for male infertility [87-89].

\section{Estrogens and Spermiogenesis}

The presence of intracellular (ER $\alpha$ and ER $\beta$ ) and transmembrane (GPR30) $\mathrm{E}_{2}$ receptors in the testis and in particular the expression of ER $\beta$, GPR30, and aromatase in germ cells have highlighted the physiological role of the $\mathrm{E}_{2}$ in spermatogenesis $[35,90]$. Aromatase knockouts (ArKO) or ER $\alpha$ knockouts $(\alpha \mathrm{ERKO})$ have further accentuated the role of $\mathrm{E}_{2}$ in germ cell progression and maturation. Indeed, the specific phenotypes have demonstrated that in $\alpha$ ERKO mice disruption of spermatogenesis appears to be primarily linked to mechanical defect in the epididymis [1], whereas in ArKO mice a specific depletion in developing SPT seems to occur [91]. To date, no helpful information came from ER $\beta$ or GPR30 knockout mice $[2,33,34]$.

Traditionally, testosterone and $\mathrm{E}_{2}$ were considered male only and female only hormones, respectively. However, at the beginning of the 1930s, the developmental exposure to high doses of $\mathrm{E}_{2}$ was reported to induce malformation of the male reproductive tract in mammals [92], thus suggesting that $\mathrm{E}_{2}$ might regulate male reproduction [2,93]. It is now accepted that $\mathrm{E}_{2}$ regulate spermatogenesis (gonocyte and spermatogonia proliferation, meiosis, Sertoli cell function) as well as spermiation, sperm transport, and epididymal sperm maturation. Some of these functions are evolutionarily conserved since they have been observed in mammalian and nonmammalian species $[1,7,8,12,14,19,36,94-99]$.

The first evidence that $E_{2}$ affect spermiogenesis came in 1987, when adult male rats were treated with an ovarian protein able to inhibit aromatase activity. After treatment, animals showed degeneration of round SPT and a massive decrease of elongated SPT $[100,101]$. Accordingly, a significant decrease in round and elongated SPT, but not in earlier germ cells, was found in adult male bonnet monkeys treated with an aromatase inhibitor for 150 days [102]. These data are not surprising, given the more intense immunostaining and higher aromatase activity in SPT than in any other testicular cells $[103,104]$.

To well define the role of $E_{2}$ in male germ cell development, mice with a targeted disruption of the cyp19A1 aromatase gene (ArKO mice) were generated [91]. These animals were initially fertile but developed progressive infertility between 4.5 months and 1 year. Spermatogenesis is primarily arrested at early spermiogenic stages, with the appearance of multinucleated cell into the tubular lumen. Furthermore, an abnormal acrosome development with multiple acrosomal vesicles and uneven spreading over the nuclear surface is also observed [91]. This observation suggests that acrosome biogenesis may be an $\mathrm{E}_{2}$-dependent process. Accordingly, aromatase is detected at high levels in the Golgi complex of developing SPT [34]. The progressive nature of the phenotype may be intrinsic to the mechanism of $\mathrm{E}_{2}$ action in adult seminiferous epithelium, as observed also in female ArKO mice, characterized by a progressive phenotype too [91]. Alternatively, the delayed phenotype may be explained by the high content of phytoestrogens in the diet, which may supply sufficient exogenous $\mathrm{E}_{2}$ to maintain normal spermatogenesis in young animals. Indeed, in young ArKO mice on a phytoestrogens-free diet, the phenotype was more severe than in mice on normal diet $[105,106]$.

However, ArKO mice are not an ideal model to study $\mathrm{E}_{2}$-regulated events during spermatogenesis in adulthood because of developmental absence of $E_{2}$. Therefore, using rat and mouse, several attempts were carried out to create conditions of high intratesticular $\mathrm{E}_{2}$ levels and study its effect on spermatogenesis.

Earlier studies on long-term exposure to pharmacological doses of $E_{2}$ in adult male rats demonstrated that this treatment suppressed both gonadotropins and testosterone releases and induced complete azoospermia [107]. Then, a second attempt was based on the administration of different doses of exogenous $E_{2}$ over a period of 10 days to increase intratesticular $\mathrm{E}_{2}$ levels with a concomitant deficiency in circulating FSH and both plasma and intratesticular testosterone. By exploiting these experimental conditions, it was suggested that, during spermiogenesis, round SPT differentiation (steps 1 to 6) was largely dependent on $\mathrm{E}_{2}$, whereas SPT elongation (steps 8 to 19) was androgen dependent [108]. These data were supported by the observation that high intratesticular $\mathrm{E}_{2}$ levels preserved round SPT steps 1-6 whereas testosterone deficiency, induced by $\mathrm{E}_{2}$ treatment via a negative central feedback, in turn originated pyknotic bodies in elongated/condensed SPT steps 8-19 [108]. In a further study, a similar treatment in rats significantly decreased testicular levels of CREM $\tau$ protein, as well as the CREM $\tau$ inducible TNP1/2 and PRM1 proteins, while the relative mRNA levels were not changed [109]. In the same article, the $\mathrm{E}_{2}$ treatment was also reported to significantly increase testicular androgen binding protein ( $\mathrm{ABP}$ ) mRNA levels, thus suggesting a specific stimulatory effect of $\mathrm{E}_{2}$ on $\mathrm{ABP}$ gene regulation or RNA stability. Authors concluded that $E_{2}$ suppressed the appropriate translation of the spermatidal proteins through an ABP-dependent posttranscriptional mechanism. Surprisingly, no information about testicular morphology was reported [109]. A further confirmation of $\mathrm{E}_{2}$ activity on SPT came from the observation that GPR30 regulates expression of apoptotic markers in rat pachytene SPC and round SPT $[90,110]$. More interestingly, growing pieces of evidence reveal that endocrine disruptors, that is, environmental pollutants able to interfere with endogenous endocrine system, have been demonstrated to negatively affect spermatogenesis; among these, there are disruptors with agonistic and antagonistic estrogenic effects. To date, this is a matter of debate and concern because these compounds may have damaging outcome on animal and human fertility [111].

Recent findings reveal that $\mathrm{E}_{2}$ restore spermatogenesis in hypogonadal (hpg) mice. Due to a natural Gnrh gene deletion, the $h p g$ mice are functionally deficient in gonadotropins and sex steroids and show meiosis arrest at pachytene stage. Treatment with $\mathrm{E}_{2}$ or $\mathrm{ER} \alpha$ agonist restores meiosis in these animals which, in absence of testosterone, produce haploid elongated SPT, likely via a mechanism involving a weak neuroendocrine activation of FSH secretion [112-114]. Qualitatively complete spermatogenesis could be also restored in $h p g$ mice 
by administration of either testosterone or its metabolite, the potent nonaromatizable androgen dihydrotestosterone (DHT), in absence of FSH stimulation [115]. However, in this case, a possible $\mathrm{E}_{2}$ involvement cannot be excluded. Indeed, it has been reported that DHT can be converted in $3 \beta$-diol by $3 \beta$-hydroxysteroid dehydrogenase $(3 \beta$-HSD), which preferentially binds ER rather than androgen receptor [116]. Interestingly, in addition to th results obtained in hpg mice [112-114], studies on FSH-receptor knockout mice (FORKO) support an $\mathrm{E}_{2}$ involvement in spermiogenesis, likely in a synergistic or independent way with FSH and/or androgens [117]. Indeed, FORKO mice show low testosterone and $E_{2}$ levels [118], as well as a significant increase of spermatogonia, decrease of elongated SPT, and weight loss of testis, epididymis, and seminal vesicles. Tubular and luminal diameters of caput epididymis appear smaller than those of wild-type males with few lumina filled with SPZ [117]. At molecular level, deprivation of FSH signaling greatly decreases TNP/PRM levels as well as chromatin quality of SPZ [119].

We recently characterized the reproductive phenotype of type 1 cannabinoid receptor knockout $\left(\mathrm{Cnr}^{-/-}\right)$male mice. These mutants exhibit endocrine and phenotypic features which are useful to extend the above studies about the role of $\mathrm{E}_{2}$ in SPT differentiation and in particular in the maintenance of sperm chromatin quality. Main features are summarized in Table 1 and described below.

\section{Reproductive Phenotype of $\mathrm{Cnr}^{-/-}$Male Mice: $\mathbf{E}_{2}$ Activity on Sperm Quality}

Endocannabinoids are lipidic mediators identified in several peripheral tissues (brain, testis, and epididymis) and biological fluids (follicular fluid, maternal milk, and blood) [4, 124-129]. To date, the best characterized are arachidonoylethanolamide (AEA or anandamide) and 2-arachidonoylglycerol (2-AG), but other molecules have been proposed as possible cannabinoid receptor (CNR) agonists $[26,130]$. Endocannabinoids regulate reproduction, in both males [16, $17,20,26,122,131-139]$ and females [140-145], and specific G-protein-coupled cannabinoid receptors, CNR1 and CNR2 (or CB1 and CB2, resp.), have been localized in male and female reproductive tracts $[20,146-148]$. In the testis, CNR1 is present in somatic and germ cells including SPT, from round stage onward [122, 129, 131, 149-154], and recently its involvement in chromatin packaging during SPT differentiation has been reported $[26,85]$. However, much remains to be clarified about a direct and/or indirect role. In vivo studies, using nonmammalian and mammalian animal models, show that CNR1 acts at both central and local level $[155,156]$. In frog, an intriguing CNR1-GnRH (gonadotropin-releasing hormone) interplay occurs at a central level, with CNR1 regulating GnRH synthesis [16]; at testicular level, CNR1 also regulates $G n R H 1 / 2$ and $G n R H-R$ (GnRH-receptor) expression [157]. In rat, CNR1 regulates the release of hypothalamic GnRH [158], while in mice it increases Tnp2 expression in the testis [85]. It has been hypothesized [26] that testicular AEA, responsive to E2 and produced by somatic cells $[131,159]$ and/or by SPT
TABLE 1: Reproductive phenotype of $\mathrm{Cnr} \mathrm{1}^{-/-}$male mice and related references.

Hypothalamus-pituitary-testis axis

(i) Normal pituitary LH content [120]

(ii) Low serum LH concentration [120]

(iii) Low testicular testosterone secretion [120]

(iv) Low circulating testosterone and $\mathrm{E}_{2}$ levels $[120,121]$

(v) High pituitary GnRH-R and low FSH $\beta$ subunit mRNA levels [121]

(vi) Low testicular Fsh-R mRNA levels [121]

(vii) Low testicular P450 mRNA levels [121]

(viii) Low P450arom levels in Leydig cells [121]

(ix) Low Tnp2 levels (both mRNA and protein) [85]

Adult Leydig cell

(i) Low number of adult Leydig cells [122]

(ii) Normal 3- $\beta$ Hsd mRNA levels/Leydig cell [121]

Sperm chromatin quality

(i) High number of SPZ with retained histones [85, 121, 123]

(ii) High number of SPZ with uncondensed chromatin $[85,123]$

(iii) High number of SPZ with DNA damage [85, 123]

(iv) SPZ with high $\%$ of damaged DNA [85]

(v) Increase of DNA damage during epididymal transit from caput to cauda [85]

(vi) High mean values of sperm nuclear length [123]

Epididymal sperm motility acquisition

(i) High number of potentially motile SPZ in caput [4]

(ii) Precocious sperm motility acquisition in caput epididymis [4]

[140], may act as paracrine/autocrine factor on SPT themselves via CNR1, by regulating Tnp2 mRNA transcription or stability.

Most information about CNR1 involvement in male reproduction came from $\mathrm{Cnr1^{-/- }}$ mice. An early study reported that $\mathrm{Cnr}^{-/-}$male efficiently synthesizes the gonadotropin LH but shows low levels of LH and testosterone in the bloodstream. Furthermore, $\mathrm{Cnr} \mathrm{1}^{-/-}$testis produces few testosterone in vitro [120]. Recently, we have characterized the reproductive phenotype of $\mathrm{Cnr} 1^{-/-}$mice and reported that males show normal progression of spermatogenesis [3, $4,122]$, produce SPZ [3, 4], and are fertile [85] although they displayed a lot of abnormalities (see Table 1 and references herein) such as (i) downregulation of neuroendocrine axis [121], (ii) developmental decrease of Leydig cell number [122], (iii) low sperm chromatin quality $[85,121]$, and (iv) abnormal epididymal sperm motility (i.e., potential to move) acquisition $[3,4]$. Some of these abnormalities well fit with the early data reported by Wenger et al. [120]. Indeed, at molecular level Cnrl gene deletion originates a ligand-dependent downregulation of GnRH-R signaling and this may explain the LH drop originally observed in these animals. In any case, although both $\mathrm{LH}$ and testosterone decrease by $50 \%$ in serum of $\mathrm{Cnr} 1^{-/-}$as compared with wild-type mice [120], we found 
that $\mathrm{LH}$ signaling is sufficient to regulate steroidogenesis supporting testosterone production in Leydig cells. Indeed, the $3 \beta$-HSD, a LH-responsive selective marker of Leydig cells, is synthesized at normal levels in individual single cells [121], thus suggesting that in $\mathrm{Cnr}^{-/-}$mice the testosterone decrease, in both in vivo and in vitro systems [120], is exclusively related to a decrease of Leydig cell number. We also found that $\mathrm{GnRH}$ downregulation is accompanied by downregulation of Fshb, Fsh-R, Tnp2, and P450arom mRNA as well as of TNP2 and P450arom protein. The P450arom protein decrease is observed in the interstitial Leydig cells and the low levels are independent by Leydig cells number. Simultaneously, low $\mathrm{E}_{2}$ levels were detected in the bloodstream suggesting that, in the mutant mice, the downregulation of neuroendocrine axis interferes with gene expression of Tnp2 in SPT as well as of P450arom in Leydig rather than in germ cells with consequent reduction of $\mathrm{E}_{2}$ levels in the bloodstream [121].

The morphological and biochemical evaluations of epididymal $\mathrm{Cnr} \mathrm{1}^{-/-}$sperm samples showed a lot of abnormalities. In wild-type animals, a 2-AG gradient (high level in caput versus low levels in cauda) prevents sperm motility acquisition in caput through the inhibitory activation of CNR1. In knockout animals, a high number of SPZ from caput epididymis appears motile, thus demonstrating that, in absence of CNR1, SPZ precociously acquire their potential to move [4]. The morphological and biochemical analyses of epididymal $\mathrm{Cnr} \mathrm{1}^{-/-} \mathrm{SPZ}$ also showed poor chromatin quality $[26,85]$. In particular, we found that the genetic inactivation of Cnrl affects chromatin remodeling mechanisms that occur in SPT during spermiogenesis. Indeed, in caput epididymis from $\mathrm{Cnr} \mathrm{1}^{-/-}$animals, the number of SPZ with histone retention as well as the number of SPZ with uncondensed chromatin or with DNA damage is higher than in $\mathrm{Cnr} \mathrm{I}^{+/+}$ and $\mathrm{Cnr} \mathrm{1}^{+/-}$animals $[85,121,123]$ demonstrating that in these animals spermiogenesis is qualitatively inefficient. Despite that, animals retain their fertility [85], likely because of a sufficient number of SPZ with mature chromatin. Correlation analysis and morphological studies also showed that abnormal histone retention is strictly related to uncondensed chromatin or DNA damage as well as it is associated to sperm nuclear size elongation. Intriguingly, histone displacement and chromatin condensation normally occur in a rostral-tocaudal direction [89] and then the failure of these mechanisms might be responsible of the nuclear swelling along its longitudinal axes. Recent experiments suggest that low plasma $\mathrm{E}_{2}$ levels might be the cause of the sperm chromatin imperfections observed in these animals [123]. Indeed, 24day postpartum $\mathrm{Cnr} \mathrm{1}^{-/-}$male mice exposed to low doses of $\mathrm{E}_{2}$, every other day for a complete cycle of spermatogenesis, showed a weak upregulation of neuroendocrine axis (no effect on $G n R H$ mRNA levels; strong increase of $G n R H-R$ mRNA; weak increase of Fshb subunit, Fsh-R, and P450arom mRNA; weak increase, about $20 \%$, of P450arom protein in Leydig cells; no effect on Tnp2 mRNA) and the rescue of sperm chromatin quality indices (histone content, chromatin condensation, DNA damage, and nuclear size), via an ER mediated mechanism [121]. Several studies propose that chromatin condensation and DNA damage are related to each other and are secondary effects associated to disrupted histone displacement $[29,56]$. Therefore, it is plausible to conclude that $\mathrm{E}_{2}$ treatment, through a TNP2-independent effect, primarily affects histone displacement and sequentially induce the rescue of sperm chromatin quality indices to physiological values. In agreement, caput SPZ from rat chronically injected with $\mathrm{E}_{2}$ showed a TNP/PRM1-independent chromatin hypercompaction [109]. In addition, serum concentration of $\mathrm{E}_{2}$ and free T4 inversely correlates with sperm DNA damage in men from an infertility clinic [160]. Furthermore, it has been reported that $\mathrm{E}_{2}$ delay testicular cell damage, which leads to functional senescence. Therefore, $\mathrm{E}_{2}$ are helpful in protecting the reproductive functions from the adverse effects exerted by reactive oxygen species (ROS) produced in large quantities in the aged testis [161].

These results, in combination with aforementioned data, show that $\mathrm{E}_{2}$, indirectly via stimulatory effects on FSH secretion and/or directly via paracrine actions within the testis, play a key role in spermiogenesis since they preserve chromatin packaging in SPT and then sperm quality. Interestingly, sperm nuclear length, which is related to chromatin quality, appears to be an $\mathrm{E}_{2}$-responsive morphological parameter [123] and may be used as helpful tool to discriminate "in real time," among morphologically normal SPZ, those with a good chromatin quality. To date, no tool exists to verify "in real time" sperm chromatin quality. Interestingly, in assisted reproduction technique field, abnormal nuclear size of human SPZ is commonly considered to be of poor prognosis [162]. More interestingly, a recent article describes a tight correlation between percentage of SPZ with nuclear form abnormalities, screened by MSOME (motile sperm organelle morphology examination) technique, and DNA fragmentation [163].

\section{Last Considerations and Conclusions}

Studies on $\alpha \mathrm{ERKO}$ mice led to conclude that $\mathrm{E}_{2}$ are involved in epididymal sperm maturation. Our data and those reported in the literature suggest a further and intriguing role for $\mathrm{E}_{2}$ in spermiogenesis and in maintenance of sperm chromatin quality. The main future endpoint will be the characterization of $\mathrm{E}_{2}$ mechanisms to better understand whether its action is direct and/or mediated. Indeed, it is still a matter of debate whether $\mathrm{E}_{2}$ and/or FSH affect chromatin remodeling in SPT in either a synergistic or an independent way with androgens [31]. Gene deletion animal models have revealed that both FSH and testosterone levels are implicated in the regulation of chromatin condensation during spermiogenesis [31]. However, although is emerging idea is that these hormones may act in synergy $[31,164]$, it has been reported in rat that the inhibition of $\mathrm{FSH}$, resulted from hyperprolactinemia induction, reduces chromatin packaging in an androgen-independent way.

Apart from the divergences, FORKO mice exhibit endocrine and phenotypic features of $\mathrm{Cnr}^{-/-}$male mice, including reduced histone displacement, enlarged sperm head size, decreased chromatin quality of SPZ (low packaging and high DNA damage), and low levels of testosterone and $\mathrm{E}_{2}$ [117-119]. 
In $\mathrm{Cnr} \mathrm{1}^{-/-}$, the number of SPZ and epididymal epithelium morphology, both dependent on testosterone [165], are not affected [3] suggesting that, in mutant mice, testosterone ranges within levels sufficient to support spermatogenesis. Therefore, we speculate that, in $C n r 1^{-/-}$mice, $\mathrm{E}_{2}$ action, (i.e., the rescue of histone displacement in SPT and chromatin quality in SPZ) is independent of testosterone. Our future endpoint will be to confirm if this really occurs and to establish $\mathrm{E}_{2}$ and FSH roles. The importance of these studies is corroborated by the growing pieces of evidence that $\mathrm{E}_{2}$ activity can be mimicked or antagonized by estrogenic environmental chemicals with potentially damaging effects on animal and human fertility [111].

\section{Abbreviations}

\begin{tabular}{|c|c|}
\hline SPC: & Spermatocytes \\
\hline SPT: & Spermatids \\
\hline SPZ: & Spermatozoa \\
\hline $\mathrm{E}_{2}:$ & Estrogens \\
\hline ER: & Estrogen receptor \\
\hline $\mathrm{Cnr1}^{-/-}:$ & Type 1 cannabinoid receptor knockout \\
\hline TNP: & Transition proteins \\
\hline PRM: & Protamines \\
\hline MARs: & Nuclear matrix attachment regions \\
\hline TBP: & TATA-box protein \\
\hline CREM: & cAMP-responsive element modulator \\
\hline CRE: & cAMP-responsive element \\
\hline $\operatorname{CREM} \tau:$ & CREMtau \\
\hline DNMT1: & DNA methyltransferase 1 \\
\hline BRDT: & Testis-specific bromodomain protein \\
\hline GPR30: & Transmembrane E2 receptor \\
\hline ArKO: & Aromatase knockouts \\
\hline$\alpha \mathrm{ERKO}$ & $\mathrm{ER} \alpha$ knockouts \\
\hline ABP: & Androgen binding protein \\
\hline Hpg: & Hypogonadal \\
\hline DHT: & Dihydrotestosterone \\
\hline $3 \beta$-HSD: & $3 \beta$-Hydroxysteroid dehydrogenase \\
\hline AEA: & Arachidonoylethanolamide \\
\hline 2-AG: & 2-Arachidonoyl-glycerol \\
\hline CNR: & Cannabinoid receptor \\
\hline GNRH: & Gonadotropin-releasing hormone \\
\hline GNRH-R: & GnRH-receptor \\
\hline ROS: & Reactive oxygen species \\
\hline MSOME: & $\begin{array}{l}\text { Motile sperm organelle morphology } \\
\text { examination }\end{array}$ \\
\hline & FSH-receptor knockout mice. \\
\hline
\end{tabular}

\section{Conflict of Interests}

The authors declare that there is no conflict of interests regarding the publication of this paper.

\section{Acknowledgments}

The authors are grateful to Dr. Diana Ferrara for English editing and critical analysis of the paper. This work was supported by Grants PRIN Pierantoni 2008 and PRIN Cobellis 20102011.

\section{References}

[1] R. A. Hess, D. Bunick, K.-H. Lee et al., "A role for oestrogens in the male reproductive system," Nature, vol. 390, no. 6659, pp. 509-512, 1997.

[2] L. O'Donnell, K. M. Robertson, M. E. Jones, and E. R. Simpson, "Estrogen and spermatogenesis," Endocrine Reviews, vol. 22, no. 3, pp. 289-318, 2001.

[3] G. Ricci, G. Cacciola, L. Altucci et al., "Endocannabinoid control of sperm motility: the role of epididymus," General and Comparative Endocrinology, vol. 153, no. 1-3, pp. 320-322, 2007.

[4] G. Cobellis, G. Ricci, G. Cacciola et al., "A gradient of 2-arachidonoylglycerol regulates mouse epididymal sperm cell start-up," Biology of Reproduction, vol. 82, no. 2, pp. 451-458, 2010.

[5] S. Fasano, M. D’Antonio, P. Chieffi, G. Cobellis, and R. Pierantoni, "Chicken GnRH-II and salmon GnRH effects on plasma and testicular androgen concentrations in the male frog, Rana esculenta, during the annual reproductive cycle," Comparative Biochemistry and Physiology C, vol. 112, no. 1, pp. 79-86, 1995.

[6] S. Fasano, P. Chieffi, G. Cobellis, and R. Pierantoni, "Neuroendocrine and local control of the frog testis," Annals of the New York Academy of Sciences, vol. 839, pp. 260-264, 1998.

[7] G. Cobellis, M. Vallarino, R. Meccariello et al., "Fos localization in cytosolic and nuclear compartments in neurones of the frog, Rana esculenta, brain: an analysis carried out in parallel with GnRH molecular forms," Journal of Neuroendocrinology, vol. 11, no. 9, pp. 725-735, 1999.

[8] G. Cobellis, R. Pierantoni, S. Minucci, R. Pernas-Alonso, R. Meccariello, and S. Fasano, "c-fos Activity in Rana esculenta testis: seasonal and estradiol-induced changes," Endocrinology, vol. 140, no. 7, pp. 3238-3244, 1999.

[9] S. Minucci, G. De Rienzo, R. Di Sena et al., "Effects of multiple injections of ethane 1, 2-dimethane sulphonate (EDS) on the frog, Rana esculenta, testicular activity," Journal Experimental Zoology, vol. 287, no. 5, pp. 384-393, 2000.

[10] R. Pierantoni, G. Cobellis, R. Meccariello, and S. Fasano, "Evolutionary aspects of cellular communication in the vertebrate hypothalamo-hypophysio-gonadal axis," International Review of Cytology, vol. 218, pp. 69-141, 2002.

[11] R. Pierantoni, G. Cobellis, R. Meccariello et al., “The amphibian testis as model to study germ cell progression during spermatogenesis," Comparative Biochemistry and Physiology B, vol. 132, no. 1, pp. 131-139, 2002.

[12] G. Cobellis, R. Meccariello, G. Fienga, R. Pierantoni, and S. Fasano, "Cytoplasmic and nuclear Fos protein forms regulate resumption of spermatogenesis in the frog, Rana esculenta," Endocrinology, vol. 143, no. 1, pp. 163-170, 2002.

[13] R. Meccariello, M. Mathieu, G. Cobellis et al., "Jun localization in cytosolic and nuclear compartments in brain-pituitary system of the frog, Rana esculenta: an analysis carried out in parallel with GnRH molecular forms during the annual reproductive cycle," General and Comparative Endocrinology, vol. 135, no. 3, pp. 310-323, 2004.

[14] G. Cobellis, M. Lombardi, D. Scarpa et al., "Fra-1 activity in the frog, Rana esculenta, testis," Annals of the New York Academy of Sciences, vol. 1040, pp. 264-268, 2005.

[15] R. Meccariello, R. Chianese, D. Scarpa et al., "UBPy/MSJ-1 system during male germ cell progression in the frog, Rana esculenta," General and Comparative Endocrinology, vol. 153, no. 1-3, pp. 275-279, 2007. 
[16] R. Meccariello, M. F. Franzoni, R. Chianese et al., "Interplay between the endocannabinoid system and GnRH-I in the forebrain of the anuran amphibian Rana esculenta," Endocrinology, vol. 149, no. 5, pp. 2149-2158, 2008.

[17] R. Chianese, T. Chioccarelli, G. Cacciola et al., "The contribution of lower vertebrate animal models in human reproduction research," General and Comparative Endocrinology, vol. 171, no. 1, pp. 17-27, 2011.

[18] G. Cobellis, R. Meccariello, R. Pierantoni, and S. Fasano, "Intratesticular signals for progression of germ cell stages in vertebrates," General and Comparative Endocrinology, vol. 134, no. 3, pp. 220-228, 2003.

[19] G. Cobellis, R. Meccariello, S. Minucci, C. Palmiero, R. Pierantoni, and S. Fasano, "Cytoplasmic versus nuclear localization of fos-related proteins in the frog, Rana esculenta, testis: in vivo and direct in vitro effect of a gonadotropin-releasing hormone agonist," Biology of Reproduction, vol. 68, no. 3, pp. 954-960, 2003.

[20] R. Pierantoni, G. Cobellis, R. Meccariello et al., “Testicular gonadotropin-releasing hormone activity, progression of spermatogenesis, and sperm transport in vertebrates," Annals of the New York Academy of Sciences, vol. 1163, pp. 279-291, 2009.

[21] G. Cacciola, R. Chianese, T. Chioccarelli et al., "Cannabinoids and reproduction: a lasting and intriguing history," Pharmaceuticals, vol. 3, no. 10, pp. 3275-3323, 2010.

[22] R. Meccariello, G. Berruti, R. Chianese et al., "Structure of msj1 gene in mice and humans: a possible role in the regulation of male reproduction," General and Comparative Endocrinology, vol. 156, no. 1, pp. 91-103, 2008.

[23] R. Chianese, D. Scarpa, G. Berruti et al., "Expression and localization of the deubiquitinating enzyme mUBPy in wobbler mouse testis during spermiogenesis," General and Comparative Endocrinology, vol. 166, no. 2, pp. 289-295, 2010.

[24] R. Meccariello, G. Cobellis, G. Berruti et al., "Mouse sperm cellspecific DnaJ first homologue: an evolutionarily conserved protein for spermiogenesis," Biology of Reproduction, vol. 66, no. 5, pp. 1328-1335, 2002.

[25] A. L. Kierszenbaum and L. L. Tres, "The acrosome-acroplaxome-manchette complex and the shaping of the spermatid head," Archives of Histology and Cytology, vol. 67, no. 4, pp. 271-284, 2004.

[26] N. Battista, R. Meccariello, G. Cobellis et al., "The role of endocannabinoids in gonadal function and fertility along the evolutionary axis," Molecular and Cellular Endocrinology, vol. 355, no. 1, pp. 1-14, 2012.

[27] E. F. Oakberg, "Duration of spermatogenesis in the mouse and timing of stages of the cycle of the seminiferous epithelium," The American Journal of Anatomy, vol. 99, no. 3, pp. 507-516, 1956.

[28] J.-P. Dadoune, "Expression of mammalian spermatozoal nucleoproteins," Microscopy Research and Technique, vol. 61, no. 1, pp. 56-75, 2003.

[29] D. T. Carrell, B. R. Emery, and S. Hammoud, "Altered protamine expression and diminished spermatogenesis: what is the link?" Human Reproduction Update, vol. 13, no. 3, pp. 313-327, 2007.

[30] D. Miller, M. Brinkworth, and D. Iles, "Paternal DNA packaging in spermatozoa: more than the sum of its parts? DNA, histones, protamines and epigenetics," Reproduction, vol. 139, no. 2, pp. 287-301, 2010.

[31] M. K. Gill-Sharma, J. Choudhuri, and S. D’Souza, "Sperm chromatin protamination: an endocrine perspective," Protein and Peptide Letters, vol. 18, no. 8, pp. 786-801, 2011.
[32] G. D. Johnson, C. Lalancette, A. K. Linnemann, F. Leduc, G. Boissonneault, and S. A. Krawetz, "The sperm nucleus: chromatin, RNA, and the nuclear matrix," Reproduction, vol. 141, no. 1, pp. 21-36, 2011.

[33] S. Carreau, H. Bouraima-Lelong, and C. Delalande, "Estrogens: new players in spermatogenesis," Reproductive Biology, vol. 11, no. 3, pp. 174-193, 2011.

[34] S. Carreau, H. Bouraima-Lelong, and C. Delalande, "Estrogens in male germ cells," Spermatogenesis, vol. 1, no. 2, pp. 90-94, 2011.

[35] S. Carreau, H. Bouraima-Lelong, and C. Delalande, "Estrogens, a female hormone concerned in spermatogenesis," Advances in Medical Sciences, vol. 57, no. 1, pp. 31-36, 2012.

[36] T. F. Lucas, M. T. Pimenta, R. Pisolato, M. F. Lazari, and C. S. Porto, "17beta-estradiol signaling and regulation of Sertoli cell function," Spermatogenesis, vol. 1, no. 4, pp. 318-324, 2011.

[37] D. Churikov, I. A. Zalenskaya, and A. O. Zalensky, "Male germline-specific histones in mouse and man," Cytogenetic and Genome Research, vol. 105, no. 2-4, pp. 203-214, 2004.

[38] M. J. D’Occhio, K. J. Hengstberger, and S. D. Johnston, “Biology of sperm chromatin structure and relationship to male fertility and embryonic survival," Animal Reproduction Science, vol. 101, no. 1-2, pp. 1-17, 2007.

[39] J. Gaucher, N. Reynoird, E. Montellier, F. Boussouar, S. Rousseaux, and S. Khochbin, "From meiosis to postmeiotic events: the secrets of histone disappearance," FEBS Journal, vol. 277, no. 3, pp. 599-604, 2010.

[40] B. Drabent, C. Bode, and D. Doenecke, "Structure and expression of the mouse testicular H1 histone gene (H1t)," Biochimica et Biophysica Acta, vol. 1216, no. 2, pp. 311-313, 1993.

[41] W. Yan, L. Ma, K. H. Burns, and M. M. Matzuk, "HILS1 is a spermatid-specific linker histone H1-like protein implicated in chromatin remodeling during mammalian spermiogenesis," Proceedings of the National Academy of Sciences of the United States of America, vol. 100, no. 18, pp. 10546-10551, 2003.

[42] I. Martianov, S. Brancorsini, R. Catena et al., "Polar nuclear localization of H1T2, a histone H1 variant, required for spermatid elongation and DNA condensation during spermiogenesis," Proceedings of the National Academy of Sciences of the United States of America, vol. 102, no. 8, pp. 2808-2813, 2005.

[43] F. De Lucia, M. R. Faraone-Mennella, M. D’Erme, P. Quesada, P. Caiafa, and B. Farina, "Histone-induced condensation of rat testis chromatin: testis-specific H1t versus somatic H1 variants," Biochemical and Biophysical Research Communications, vol. 198, no. 1, pp. 32-39, 1994.

[44] M. L. Meistrich, "Histones and basic nuclear protein transitions in mammalian spermatogenesis," in Histones and Other Basic Nuclear Proteins, L. S. Hnilica, G. S. Stein, and J. L. Stein, Eds., pp. 165-182, CRC Press, Boca Raton, Fla, USA, 1989.

[45] J. Govin, C. Caron, C. Lestrat, S. Rousseaux, and S. Khochbin, "The role of histones in chromatin remodelling during mammalian spermiogenesis," European Journal of Biochemistry, vol. 271, no. 17, pp. 3459-3469, 2004.

[46] L. Marcon and G. Boissonneault, "Transient DNA strand breaks during mouse and human spermiogenesis: new insights in stage specificity and link to chromatin remodeling," Biology of Reproduction, vol. 70, no. 4, pp. 910-918, 2004.

[47] S. Rousseaux, C. Caron, J. Govin, C. Lestrat, A.-K. Faure, and S. Khochbin, "Establishment of male-specific epigenetic information," Gene, vol. 345, no. 2, pp. 139-153, 2005. 
[48] R. Oliva and J. Castillo, "Proteomics and the genetics of sperm chromatin condensation," Asian Journal of Andrology, vol. 13, no. 1, pp. 24-30, 2011.

[49] C. Pittoggi, L. Renzi, G. Zaccagnini et al., "A fraction of mouse sperm chromatin is organized in nucleosomal hypersensitive domains enriched in retroposon DNA," Journal of Cell Science, vol. 112, no. 20, pp. 3537-3548, 1999.

[50] U. Brykczynska, M. Hisano, S. Erkek et al., "Repressive and active histone methylation mark distinct promoters in human and mouse spermatozoa," Nature Structural and Molecular Biology, vol. 17, no. 6, pp. 679-687, 2010.

[51] F. Aoki, D. M. Worrad, and R. M. Schultz, "Regulation of transcriptional activity during the first and second cell cycles in the preimplantation mouse embryo," Developmental Biology, vol. 181, no. 2, pp. 296-307, 1997.

[52] P. Mali, A. Kaipia, M. Kangasniemi et al., "Stage-specific expression of nucleoprotein mRNAs during rat and mouse spermiogenesis," Reproduction, Fertility and Development, vol. 1, no. 4, pp. 369-382, 1989.

[53] W. S. Kistler, K. Henriksén, P. Mali, and M. Parvinen, "Sequential expression of nucleoproteins during rat spermiogenesis," Experimental Cell Research, vol. 225, no. 2, pp. 374-381, 1996.

[54] K. Tseden, Ö. Topaloglu, A. Meinhardt et al., "Premature translation of transition protein 2 mRNA causes sperm abnormalities and male infertility," Molecular Reproduction and Development, vol. 74, no. 3, pp. 273-279, 2007.

[55] R. P. Martins, G. Charles Ostermeier, and S. A. Krawetz, "Nuclear matrix interactions at the human protamine domain: a working model of potentiation," Journal of Biological Chemistry, vol. 279, no. 50, pp. 51862-51868, 2004.

[56] K. N. Hogeveen and P. Sassone-Corsi, "Regulation of gene expression in post-meiotic male germ cells: CREM-signalling pathways and male fertility," Human Fertility, vol. 9, no. 2, pp. 73-79, 2006.

[57] N. S. Foulkes, B. Mellstrom, E. Benusiglio, and P. Sassone-Corsi, "Development switch of CREM function during spermatogenesis: from antagonist to activator," Nature, vol. 355, no. 6355, pp. 80-84, 1992.

[58] V. Delmas, F. Van der Hoorn, B. Mellstrom, B. Jegou, and P. Sassone-Corsi, "Induction of CREM activator proteins in spermatids: down-stream targets and implications for haploid germ cell differentiation," Molecular Endocrinology, vol. 7, no. 11, pp. 1502-1514, 1993.

[59] N. S. Foulkes, F. Schlotter, P. Pevet, and P. Sassone-Corsi, "Pituitary hormone FSH direct the CREM functional switch during spermatogenesis," Nature, vol. 362, no. 6417, pp. 264-267, 1993.

[60] O. A. Omisanjo, K. Biermann, S. Hartmann et al., "DNMT1 and $\mathrm{HDAC1}$ gene expression in impaired spermatogenesis and testicular cancer," Histochemistry and Cell Biology, vol. 127, no. 2, pp. 175-181, 2007.

[61] F. Nantel and P. Sassone-Corsi, "CREM: a transcriptional master switch during the spermatogenesis differentiation program," Frontiers in Bioscience, vol. 1, pp. d266-269, 1996.

[62] J. A. Blendy, K. H. Kaestner, G. F. Weinbauer, E. Nieschlag, and G. Schütz, "Severe impairment of spermatogenesis in mice lacking the CREM gene," Nature, vol. 380, no. 6570, pp. 162-165, 1996.

[63] B. Sarg, S. Chwatal, H. Talasz, and H. H. Linder, "Testis-specific linker histone Hlt is multiply phosphorylated during spermatogenesis: identification of phosphorylation sites," Journal of Biological Chemistry, vol. 284, no. 6, pp. 3610-3618, 2009.
[64] K. Kurtz, N. Saperas, J. Ausió, and M. Chiva, "Spermiogenic nuclear protein transitions and chromatin condensation. proposal for an ancestral model of nuclear spermiogenesis," Journal of Experimental Zoology B, vol. 312, no. 3, pp. 149-163, 2009.

[65] M. L. Meistrich, P. K. Trostle-Weige, R. Lin, Y. M. Bhatnagar, and C. D. Allis, "Highly acetylated H4 is associated with histone displacement in rat spermatids," Molecular Reproduction and Development, vol. 31, no. 3, pp. 170-181, 1992.

[66] M. Hazzouri, C. Pivot-Pajot, A.-K. Faure et al., "Regulated hyperacetylation of core histones during mouse spermatogenesis: involvement of histone-deacetylases," European Journal of Cell Biology, vol. 79, no. 12, pp. 950-960, 2000.

[67] P. Sassone-Corsi, "Transcription factors governing male fertility," Andrologia, vol. 37, no. 6, pp. 228-229, 2005.

[68] J. Singh and M. R. S. Rao, "Interaction of rat testis protein, TP, with nucleosome core particle," Biochemistry International, vol. 17, no. 4, pp. 701-710, 1988.

[69] T. K. Kundu, "DNA condensation by the rat spermatidal protein TP2 shows GC-rich sequence preference and is zinc dependent," Biochemistry, vol. 34, no. 15, pp. 5143-5150, 1995.

[70] A. R. Meetei, K. S. Ullas, V. Vasupradha, and M. R. S. Rao, "Involvement of protein kinase A in the phosphorylation of spermatidal protein TP2 and its effect on DNA condensation," Biochemistry, vol. 41, no. 1, pp. 185-195, 2002.

[71] N. Caron, S. Veilleux, and G. Boissonneault, "Stimulation of DNA repair by the spermatidal TP1 protein," Molecular Reproduction and Development, vol. 58, no. 4, pp. 437-443, 2001.

[72] D. Sakkas, G. Manicardi, P. G. Bianchi, D. Bizzaro, and U. Bianchi, "Relationship between the presence of endogenous nicks and sperm chromatin packaging in maturing and fertilizing mouse spermatozoa," Biology of Reproduction, vol. 52, no. 5, pp. 1149-1155, 1995.

[73] R. Oliva and G. H. Dixon, "Vertebrate protamine genes and the histone-to-protamine replacement reaction," Progress in Nucleic Acid Research and Molecular Biology, vol. 40, pp. 25-94, 1991.

[74] A. Smith and T. Haaf, "DNA nicks and increased sensitivity of DNA to fluorescence in situ end labeling during functional spermiogenesis," BioTechniques, vol. 25, no. 3, pp. 496-502, 1998.

[75] Y. E. Yu, Y. Zhang, E. Unni et al., "Abnormal spermatogenesis and reduced fertility in transition nuclear protein 1-deficient mice," Proceedings of the National Academy of Sciences of the United States of America, vol. 97, no. 9, pp. 4683-4688, 2000.

[76] M. Zhao, C. R. Shirley, S. Hayashi et al., “Transition nuclear proteins are required for normal chromatin condensation and functional sperm development," Genesis, vol. 38, no. 4, pp. 200213, 2004.

[77] J. Ausió, J. M. Eirín-López, and L. J. Frehlick, "Evolution of vertebrate chromosomal sperm proteins: implications for fertility and sperm competition," Society of Reproduction and Fertility supplement, vol. 65, pp. 63-79, 2007.

[78] R. Oliva, "Protamines and male infertility," Human Reproduction Update, vol. 12, no. 4, pp. 417-435, 2006.

[79] C. Helene, J.-J. Toulme, T. Behmoaras, and C. Cazenave, "Mechanisms for the recognition of chemically-modified DNA by peptides and proteins," Biochimie, vol. 64, no. 8-9, pp. 697-705, 1982.

[80] R. Balhorn, M. Corzett, and J. A. Mazrimas, "Formation of intraprotamine disulfides in vitro," Archives of Biochemistry and Biophysics, vol. 296, no. 2, pp. 384-393, 1992. 
[81] J. Seligman, Y. Zipser, and N. S. Kosower, “Tyrosine phosphorylation, thiol status, and protein tyrosine phosphatase in rat epididymal spermatozoa," Biology of Reproduction, vol. 71, no. 3, pp. 1009-1015, 2004.

[82] G. S. Bench, A. M. Friz, M. H. Corzett, D. H. Morse, and R. Balhorn, "DNA and total protamine masses in individual sperm from fertile mammalian subjects," Cytometry, vol. 23, no. 4, pp. 263-271, 1996.

[83] K. Steger, L. Fink, K. Failing et al., "Decreased protamine-1 transcript levels in testes from infertile men," Molecular Human Reproduction, vol. 9, no. 5-6, pp. 331-336, 2003.

[84] V. W. Aoki, B. R. Emery, L. Liu, and D. T. Carrell, "Protamine levels vary between individual sperm cells of infertile human males and correlate with viability and DNA integrity," Journal of Andrology, vol. 27, no. 6, pp. 890-898, 2006.

[85] T. Chioccarelli, G. Cacciola, L. Altucci et al., "Cannabinoid receptor 1 influences chromatin remodeling in mouse spermatids by affecting content of transition protein 2 mRNA and histone displacement," Endocrinology, vol. 151, no. 10, pp. 50175029, 2010.

[86] S. E. M. Lewis and I. M. Agbaje, "Using the alkaline comet assay in prognostic tests for male infertility and assisted reproductive technology outcomes," Mutagenesis, vol. 23, no. 3, pp. 163-170, 2008.

[87] A. Agarwal and T. M. Said, "Role of sperm chromatin abnormalities and DNA damage in male infertility," Human Reproduction Update, vol. 9, no. 4, pp. 331-345, 2003.

[88] V. W. Aoki, L. Liu, and D. T. Carrell, "Identification and evaluation of a novel sperm protamine abnormality in a population of infertile males," Human Reproduction, vol. 20, no. 5, pp. 12981306, 2005.

[89] V. W. Aoki, S. I. Moskovtsev, J. Willis, L. Liu, J. B. M. Mullen, and D. T. Carrell, "DNA integrity is compromised in protaminedeficient human sperm," Journal of Andrology, vol. 26, no. 6, pp. 741-748, 2005.

[90] A. Chimento, R. Sirianni, C. Delalande et al., "17 $\beta$-Estradiol activates rapid signaling pathways involved in rat pachytene spermatocytes apoptosis through GPR30 and ER $\alpha$," Molecular and Cellular Endocrinology, vol. 320, no. 1-2, pp. 136-144, 2010.

[91] K. M. Robertson, L. O’Donnell, M. E. E. Jones et al., "Impairment of spermatogenesis in mice lacking a functional aromatase (cyp 19) gene," Proceedings of the National Academy of Sciences of the United States of America, vol. 96, no. 14, pp. 7986-7991, 1999.

[92] E. Wolff and A. Ginglinger, "Sur la transformation des Poulets males en intersexues par injection d'hormone femelle (folliculine) aux embryons," Archives Anatomie, Histologie et Embryologie, vol. 20, pp. 219-278, 1935.

[93] C. Staub, M. Rauch, F. Ferrière et al., "Expression of estrogen receptor ESR1 and its $46-\mathrm{kDa}$ variant in the gubernaculum testis," Biology of Reproduction, vol. 73, no. 4, pp. 703-712, 2005.

[94] P. Chieffi, S. Minucci, G. Cobellis, S. Fasano, and R. Pierantoni, "Changes in proto-oncogene activity in the testis of the frog, Rana esculenta, during the annual reproductive cycle," General and Comparative Endocrinology, vol. 99, no. 2, pp. 127-136, 1995.

[95] G. Cobellis, R. Pierantoni, and S. Fasano, "c-fos- and c-junlike mRNA expression in frog (Rana esculenta) testis during the annual reproductive cycle," General and Comparative Endocrinology, vol. 106, no. 1, pp. 23-29, 1997.

[96] H. Li, V. Papadopoulos, B. Vidic, M. Dym, and M. Culty, "Regulation of rat testis gonocyte proliferation by plateletderived growth factor and estradiol: identification of signaling mechanisms involved," Endocrinology, vol. 138, no. 3, pp. 12891298, 1997.

[97] T. Miura, C. Miura, T. Ohta, M. R. Nader, T. Todo, and K. Yamauchi, "Estradiol-17 $\beta$ stimulates the renewal of spermatogonial stem cells in males," Biochemical and Biophysical Research Communications, vol. 264, no. 1, pp. 230-234, 1999.

[98] G. Cobellis, M. Lombardi, D. Scarpa et al., "Fral activity in the frog, Rana esculenta, testis: a new potential role in sperm transport," Biology of Reproduction, vol. 72, no. 5, pp. 1101-1108, 2005.

[99] G. Cobellis, G. Cacciola, T. Chioccarelli et al., "Estrogen regulation of the male reproductive tract in the frog, Rana esculenta: a role in Fra-1 activation in peritubular myoid cells and in sperm release," General and Comparative Endocrinology, vol. 155, no. 3, pp. 838-846, 2008.

[100] I. Tsutsumi, J. Toppari, J. D. Campeau, and G. S. DiZerega, "Reduction of fertility in the male rat by systemic treatment with follicle regulatory protein," Fertility and Sterility, vol. 47, no. 4, pp. 689-695, 1987.

[101] I. Tsutsumi, K. Fugimori, and R. M. Nakamura, "Disruption of seminiferous epithelial function in the rat by ovarian protein," Biology of Reproduction, vol. 36, no. 2, pp. 451-461, 1987.

[102] G. Shetty, H. Krishnamurthy, H. N. Krishnamurthy, A. S. Bhatnagar, and N. R. Moudgal, "Effect of long-term treatment with aromatase inhibitor on testicular function of adult male bonnet monkeys (M. radiata)," Steroids, vol. 63, no. 7-8, pp. 414420, 1998.

[103] H. Nitta, D. Bunick, R. A. Hess et al., "Germ cells of the mouse testis express P450 aromatase," Endocrinology, vol. 132, no. 3, pp. 1396-1401, 1993.

[104] J. Levallet, B. Bilinska, H. Mittre, C. Genissel, J. Fresnel, and S. Carreau, "Expression and immunolocalization of functional cytochrome p450 aromatase in mature rat testicular cells," Biology of Reproduction, vol. 58, no. 4, pp. 919-926, 1998.

[105] K. M. Robertson, E. R. Simpson, O. Lacham-Kaplan, and M. E. E. Jones, "Characterization of the fertility of male aromatase knockout mice," Journal of Andrology, vol. 22, no. 5, pp. 825-830, 2001.

[106] K. M. Robertson, L. O'Donnell, E. R. Simpson, and M. E. E. Jones, "The phenotype of the aromatase knockout mouse reveals dietary phytoestrogens impact significantly on testis function," Endocrinology, vol. 143, no. 8, pp. 2913-2921, 2002.

[107] M. K. Gill-Sharma, S. D’Souza, V. Padwal et al., "Antifertility effects of estradiol in adult male rats," Journal of Endocrinological Investigation, vol. 24, no. 8, pp. 598-607, 2001.

[108] R. D'Souza, M. K. Gill-Sharma, S. Pathak, N. Kedia, R. Kumar, and N. Balasinor, "Effect of high intratesticular estrogen on the seminiferous epithelium in adult male rats," Molecular and Cellular Endocrinology, vol. 241, no. 1-2, pp. 41-48, 2005.

[109] M. Aleem, V. Padwal, J. Choudhari, N. Balasinor, P. Parte, and M. K. Gill-Sharma, "Estradiol affects androgen-binding protein expression and fertilizing ability of spermatozoa in adult male rats," Molecular and Cellular Endocrinoogy, vol. 253, no. 1-2, pp. 1-13, 2006.

[110] A. Chimento, R. Sirianni, F. Zolea et al., "Gper and ESRs are expressed in rat round spermatids and mediate oestrogendependent rapid pathways modulating expression of cyclin B1 and Bax," International Journal of Andrology, vol. 34, no. 5, pp. 420-429, 2011.

[111] R. M. Sharpe, "Environmental/lifestyle effects on spermatogenesis," Philosophical Transactions of the Royal Society B, vol. 365, pp. 1697-1712, 2010. 
[112] F. J. P. Ebling, A. N. Brooks, A. S. Cronin, H. Ford, and J. B. Kerr, "Estrogenic induction of spermatogenesis in the hypogonadal mouse," Endocrinology, vol. 141, no. 8, pp. 2861-2869, 2000.

[113] H. Baines, M. O. Nwagwu, G. R. Hastie, R. A. Wiles, T. M. Mayhew, and F. J. P. Ebling, "Effects of estradiol and FSH on maturation of the testis in the hypogonadal (hpg) mouse," Reproductive Biology and Endocrinology, vol. 6, article 4, 2008.

[114] C. M. Allan, J. F. Couse, U. Simanainen et al., "Estradiol induction of spermatogenesis is mediated via an estrogen receptor$\alpha$ mechanism involving neuroendocrine activation of folliclestimulating hormone secretion," Endocrinology, vol. 151, no. 6, pp. 2800-2810, 2010.

[115] J. Singh, C. O’Neill, and D. J. Handelsman, "Induction of spermatogenesis by androgens in gonadotropin-deficient (hpg) mice," Endocrinology, vol. 136, no. 12, pp. 5311-5321, 1995.

[116] T. R. Pak, W. C. J. Chung, T. D. Lund, L. R. Hinds, C. M. Clay, and R. J. Handa, "The androgen metabolite, $5 \alpha$-androstane- $3 \beta$, $17 \beta$ diol, is a potent modulator of estrogen receptor- $\beta 1$-mediated gene transcription in neuronal cells," Endocrinology, vol. 146, no. 1, pp. 147-155, 2005.

[117] H. Krishnamurthy, N. Danilovich, C. R. Morales, and M. R. Sairam, "Qualitative and quantitative decline in spermatogenesis of the follicle- stimulating hormone receptor knockout (FORKO) mouse," Biology of Reproduction, vol. 62, no. 5, pp. 1146-1159, 2000.

[118] D. Javeshghani, R. M. Touyz, M. R. Sairam, and E. L. Schiffrin, "Gender differences in blood pressure in estrogen-deficient FORKO mice," The American Journal of Hypertension, vol. 15, no. S3, pp. 152A-153A, 2002.

[119] W. Xing, H. Krishnamurthy, and M. R. Sairam, "Role of follitropin receptor signaling in nuclear protein transitions and chromatin condensation during spermatogenesis," Biochemical and Biophysical Research Communications, vol. 312, no. 3, pp. 697-701, 2003.

[120] T. Wenger, C. Ledent, V. Csernus, and I. Gerendai, “The central cannabinoid receptor inactivation suppresses endocrine reproductive functions," Biochemical and Biophysical Research Communications, vol. 284, no. 2, pp. 363-368, 2001.

[121] G. Cacciola, T. Chioccarelli, L. Altucci et al., "Low 17betaestradiol levels in Cnrl knock-out mice affect spermatid chromatin remodeling by interfering with chromatin reorganization," Biology of Reproduction, vol. 88, no. 6, pp. 1-12, 2013.

[122] G. Cacciola, T. Chioccarelli, K. Mackie et al., "Expression of type-1 cannabinoid receptor during rat postnatal testicular development: possible involvement in adult leydig cell differentiation," Biology of Reproduction, vol. 79, no. 4, pp. 758-765, 2008.

[123] G. Cacciola, T. Chioccarelli, A. Viggiano, S. Fasano, R. Pierantoni, and G. Cobellis, "Nuclear size as estrogen-responsive chromatin quality parameter of mouse spermatozoa," General and Comparative Endocrinology, vol. 193, pp. 201-209, 2013.

[124] W. A. Devane, L. Hanus, A. Breuer et al., "Isolation and structure of a brain constituent that binds to the cannabinoid receptor," Science, vol. 258, no. 5090, pp. 1946-1949, 1992.

[125] R. Mechoulam, S. Ben-Shabat, L. Hanuš et al., "Identification of an endogenous 2-monoglyceride, present in canine gut, that binds to cannabinoid receptors," Biochemical Pharmacology, vol. 50, no. 1, pp. 83-90, 1995.

[126] T. Sugiura, S. Kondo, A. Sukagawa et al., "Enzymatic synthesis of anandamide, an endogenous cannabinoid receptor ligand, through $\mathrm{N}$-acylphosphatidylethanolamine pathway in testis: involvement of Ca2+-dependent transacylase and phosphodiesterase activities," Biochemical and Biophysical Research Communications, vol. 218, no. 1, pp. 113-117, 1996.

[127] H. Schuel, L. J. Burkman, J. Lippes et al., "N-Acylethanolamines in human reproductive fluids," Chemistry and Physics of Lipids, vol. 121, no. 1-2, pp. 211-227, 2002.

[128] O. M. H. Habayeb, A. H. Taylor, M. D. Evans et al., "Plasma levels of the endocannabinoid anandamide in women: a potential role in pregnancy maintenance and labor?" Journal of Clinical Endocrinology and Metabolism, vol. 89, no. 11, pp. 5482-5487, 2004.

[129] G. Cobellis, G. Cacciola, D. Scarpa et al., "Endocannabinoid system in frog and rodent testis: type-1 cannabinoid receptor and fatty acid amide hydrolase activity in male germ cells," Biology of Reproduction, vol. 75, no. 1, pp. 82-89, 2006.

[130] V. Di Marzo, T. Bisogno, and L. De Petrocellis, "Endocannabinoids and related compounds: walking back and forth between plant natural products and animal physiology," Chemistry and Biology, vol. 14, no. 7, pp. 741-756, 2007.

[131] M. Maccarrone, S. Cecconi, G. Rossi, N. Battista, R. Pauselli, and A. Finazzi-Agrò, "Anandamide activity and degradation are regulated by early postnatal aging and follicle-stimulating hormone in mouse Sertoli cells," Endocrinology, vol. 144, no. 1, pp. 20-28, 2003.

[132] M. Maccarrone, B. Barboni, A. Paradisi et al., "Characterization of the endocannabinoid system in boar spermatozoa and implications for sperm capacitation and acrosome reaction," Journal of Cell Science, vol. 118, no. 19, pp. 4393-4404, 2005.

[133] R. Chianese, G. Cobellis, R. Pierantoni, S. Fasano, and R. Meccariello, "Non-mammalian vertebrate models and the endocannabinoid system: relationships with gonadotropin-releasing hormone," Molecular and Cellular Endocrinology, vol. 286, no. 1-2, pp. S46-S51, 2008.

[134] G. Cacciola, T. Chioccarelli, G. Ricci et al., "The endocannabinoid system in vertebrate male reproduction: a comparative overview," Molecular and Cellular Endocrinology, vol. 286, no. 1-2, pp. S24-S30, 2008.

[135] X. Sun, H. Wang, M. Okabe et al., "Genetic loss of Faah compromises male fertility in mice," Biology of Reproduction, vol. 80, no. 2, pp. 235-242, 2009.

[136] F. Francavilla, N. Battista, A. Barbonetti et al., "Characterization of the endocannabinoid system in human spermatozoa and involvement of transient receptor potential vanilloid 1 receptor in their fertilizing ability," Endocrinology, vol. 150, no. 10, pp. 4692-4700, 2009.

[137] S. E. Lewis and M. Maccarrone, "Endocannabinoids, sperm biology and human fertility," Pharmacological Research, vol. 60, no. 2, pp. 126-131, 2009.

[138] R. Meccariello, R. Chianese, G. Cacciola, G. Cobellis, R. Pierantoni, and S. Fasano, "Type-1 cannabinoid receptor expression in the frog, Rana esculenta, tissues: a possible involvement in the regulation of testicular activity," Molecular Reproduction and Development, vol. 73, no. 5, pp. 551-558, 2006.

[139] S. E. M Lewis, R. Paro, L. Borriello et al., "Long-term use of HU210 adversely affects spermatogenesis in rats by modulating the endocannabinoid system," International Journal of Andrology, vol. 35, no. 5, pp. 731-740, 2012.

[140] N. Lazzarin, H. Valensise, M. Bari et al., "Fluctuations of fatty acid amide hydrolase and anandamide levels during the human ovulatory cycle," Gynecological Endocrinology, vol. 18, no. 4, pp. 212-218, 2004. 
[141] M. Maccarrone, E. Fride, T. Bisogno et al., "Up-regulation of the endocannabinoid system in the uterus of leptin knockout (ob/ob) mice and implications for fertility," Molecular Human Reproduction, vol. 11, no. 1, pp. 21-28, 2005.

[142] H. Wang, H. Xie, X. Sun et al., "Differential regulation of endocannabinoid synthesis and degradation in the uterus during embryo implantation," Prostaglandins and Other Lipid Mediators, vol. 83, no. 1-2, pp. 62-74, 2007.

[143] G. Acone, E. Trabucco, N. Colacurci et al., "Low type I cannabinoid receptor levels characterize placental villous in labouring delivery," Placenta, vol. 30, no. 2, pp. 203-205, 2009.

[144] E. Trabucco, G. Acone, A. Marenna et al., "Endocannabinoid system in first trimester placenta: low FAAH and high CB1 expression characterize spontaneous miscarriage," Placenta, vol. 30, no. 6, pp. 516-522, 2009.

[145] X. Sun and S. K. Dey, "Endocannabinoid signaling in female reproduction," ACS Chemical Neuroscience, vol. 3, no. 5, pp. 349-355, 2012.

[146] R. G. Pertwee, G. Joe-Adigwe, and G. M. Hawksworth, "Further evidence for the presence of cannabinoid CB1 receptors in mouse vas deferens," European Journal of Pharmacology, vol. 296, no. 2, pp. 169-172, 1996.

[147] P. Grimaldi, P. Orlando, S. Di Siena et al., “The endocannabinoid system and pivotal role of the CB2 receptor in mouse spermatogenesis," Proceedings of the National Academy of Sciences of the United States of America, vol. 106, no. 27, pp. 11131-11136, 2009.

[148] T. Karasu, T. H. Marczylo, M. Maccarrone, and J. C. Konje, "The role of sex steroid hormones, cytokines and the endocannabinoid system in female fertility," Human Reproduction Update, vol. 17, no. 3, Article ID dmq058, pp. 347-361, 2011.

[149] M. C. Gye, H. H. Kang, and H. J. Kang, "Expression of cannabinoid receptor 1 in mouse testes," Archives of Andrology, vol. 51, no. 3, pp. 247-255, 2005.

[150] M. Rossato, F. I. Popa, M. Ferigo, G. Clari, and C. Foresta, "Human sperm express cannabinoid receptor Cb1, the activation of which inhibits motility, acrosome reaction, and mitochondrial function," Journal of Clinical Endocrinology and Metabolism, vol. 90, no. 2, pp. 984-991, 2005.

[151] A. Barbonetti, M. R. C. Vassallo, D. Fortunato, S. Francavilla, M. Maccarrone, and F. Francavilla, "Energetic metabolism and human sperm motility: impact of CB1 receptor activation," Endocrinology, vol. 151, no. 12, pp. 5882-5892, 2010.

[152] B. Barboni, N. Bernabò, P. Palestini et al., “Type-1 Cannabinoid receptors reduce membrane fluidity of capacitated boar sperm by impairing their activation by bicarbonate," PLOS ONE, vol. 6 , no. 8, Article ID e23038, 2011.

[153] G. Catanzaro, N. Battista, G. Rossi et al., "Effect of capacitation on the endocannabinoid system of mouse sperm," Molecular and Cellular Endocrinology, vol. 343, no. 1-2, pp. 88-92, 2011.

[154] N. Bernabò, P. Palestini, M. Chiarini, M. Maccarrone, M. Mattioli, and B. Barboni, "Endocannabinoid-binding CB1 and TRPV1 receptors as modulators of sperm capacitation," Communicative and Integrative Biology, vol. 5, no. 1, pp. 68-70, 2012.

[155] R. Pierantoni, G. Cobellis, R. Meccariello et al., "CB1 activity in male reproduction: mammalian and nonmammalian animal models," Vitamins and Hormones, vol. 81, pp. 367-387, 2009.

[156] S. Fasano, R. Meccariello, G. Cobellis et al., "The endocannabinoid system: an ancient signaling involved in the control of male fertility," Annals of the New York Academy of Sciences, vol. 1163, no. 1, pp. 112-124, 2009.
[157] R. Chianese, V. Ciaramella, D. Scarpa, S. Fasano, R. Pierantoni, and R. Meccariello, "Anandamide regulates the expression of GnRH1, GnRH2, and GnRH-Rs in frog testis," The American Journa Physioly Endocrinology and Metabolism, vol. 303, no. 4, pp. 475-487, 2012.

[158] C. Scorticati, J. Fernández-Solari, A. De Laurentiis et al., "The inhibitory effect of anandamide on luteinizing hormonereleasing hormone secretion is reversed by estrogen," Proceedings of the National Academy of Sciences, vol. 101, no. 32, pp. 1189111896, 2004.

[159] P. Grimaldi, M. Pucci, S. Di Siena et al., "The faah gene is the first direct target of E2 in the testis: role of histone demethylase LSD1," Cellullar Molecular Life Science, vol. 69, no. 24, pp. 41774190, 2012.

[160] J. D. Meeker, N. P. Singh, and R. Hauser, "Serum concentrations of estradiol and free T4 are inversely correlated with sperm DNA damage in men from an infertility clinic," Journal of Andrology, vol. 29, no. 4, pp. 379-388, 2008.

[161] K. Hamden, D. Silandre, C. Delalande, A. Elfeki, and S Carreau, "Protective effects of estrogens and caloric restriction during aging on various rat testis parameters," Asian Journal of Andrology, vol. 10, no. 6, pp. 837-845, 2008.

[162] B. Bartoov, A. Berkovitz, F. Eltes, A. Kogosowski, Y. Menezo, and Y. Barak, "Real-time fine morphology of motile human sperm cells is associated with IVF-ICSI outcome," Journal of Andrology, vol. 23, no. 1, pp. 1-8, 2002.

[163] J. B. Oliveira, F. C. Massaro, R. L. Baruffi et al., "Correlation between semen analysis by motile sperm organelle morphology examination and sperm DNA damage," Fertility and Sterility, vol. 94, no. 5, pp. 1937-1940, 2010.

[164] S. M. Ruwanpura, R. I. McLachlan, and S. J. Meachem, "Hormonal regulation of male germ cell development," Journal of Endocrinology, vol. 205, no. 2, pp. 117-131, 2010.

[165] R. Jones, "Sperm survival versus degradation in the mammalian epididymis: an hypothesis," Biology of Reproduction, vol. 71, no. 5, pp. 1405-1411, 2004. 


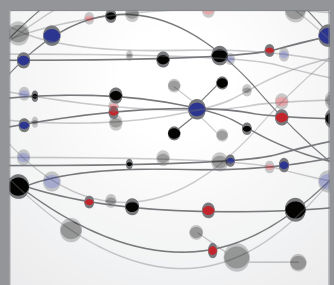

The Scientific World Journal
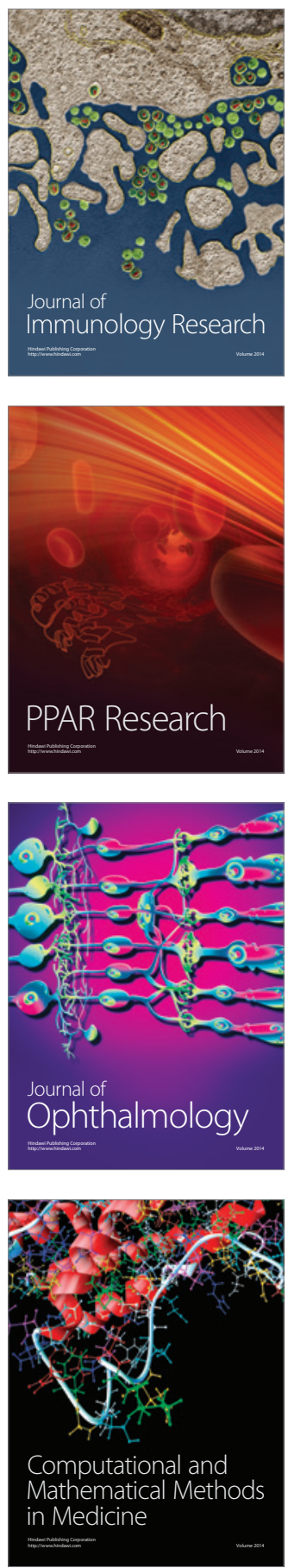

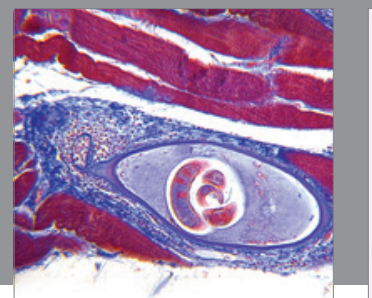

Gastroenterology

Research and Practice
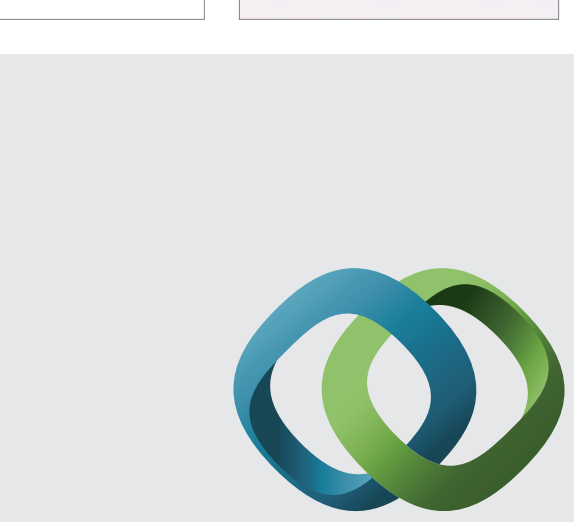

\section{Hindawi}

Submit your manuscripts at

http://www.hindawi.com
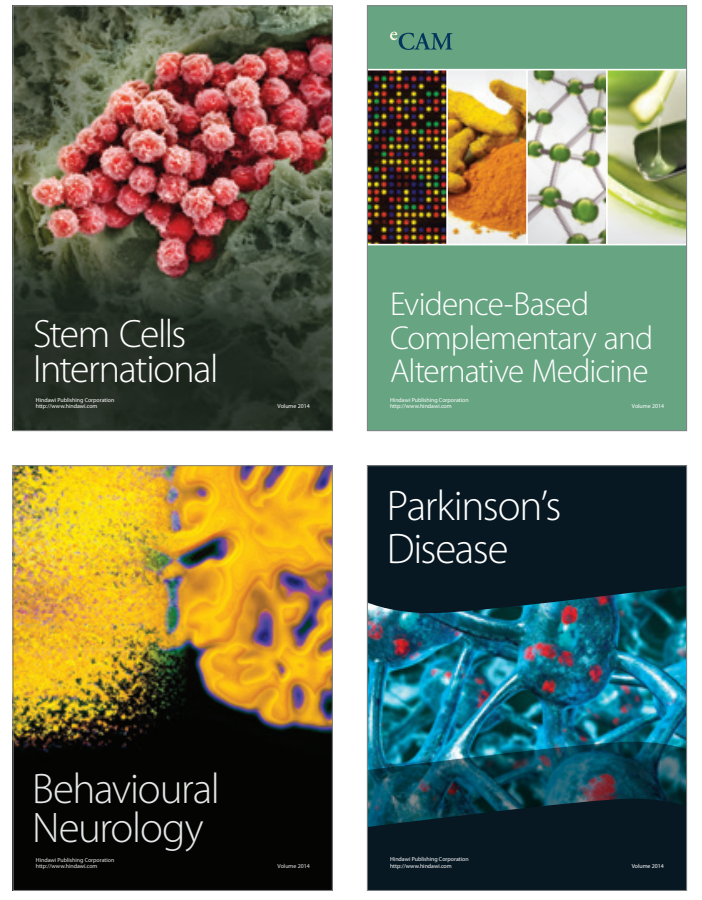
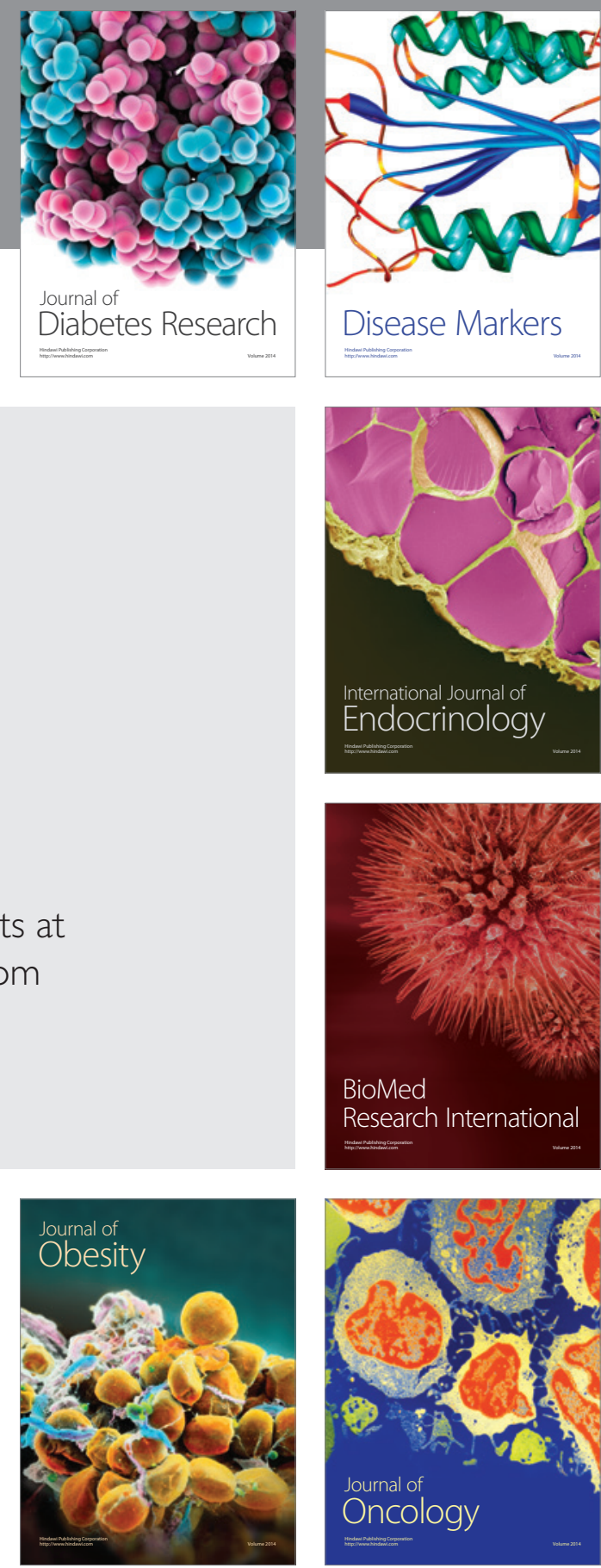

Disease Markers
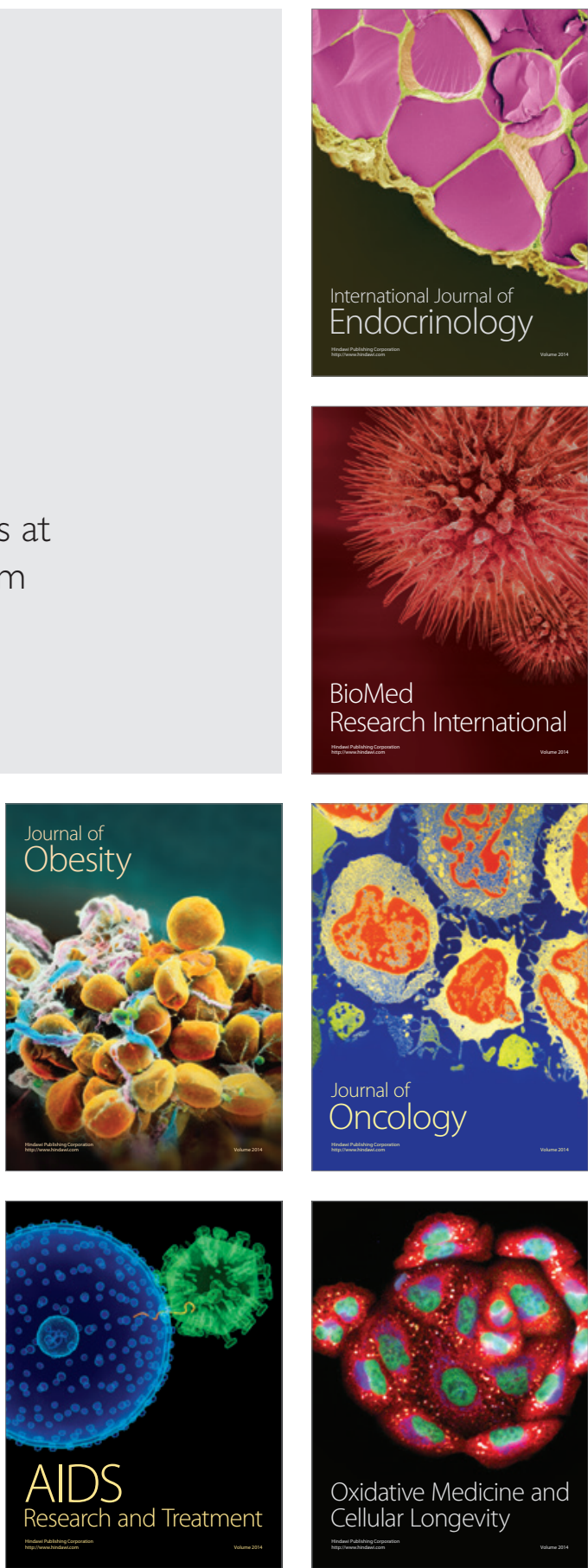